\title{
Formulasi dan Evaluasi Hidrogel Mukoadhesif Metronidazol Menggunakan Kombinasi Kitosan dan Natrium Karboksimetilselulosa Menggunakan Desain Faktorial
}

Andhi Fahrurroji*, Agus Setyawan, Bambang Wijianto

Prodi Farmasi, Fakultas Kedokteran, Universitas Tanjungpura, Pontianak

*Corresponding author: roji_apt@pharm.untan.ac.id

Submitted: 27 Februari 2019

Accepted: 25 Juni 2019

Published online: 31 juli 2019

\begin{abstract}
Background: Metronidazole is an antibiotic that is commonly used to treat Helicobacter pylori infection. Metronidazole is highly soluble in acid. In order to optimize the solubility, mucoadhesive hydrogels were formulated to maintain longer retention time in the stomach in order to optimize therapy for H.pylori infection. Objective: The purpose of this research was to obtain optimum formula of polymer hydrogels with combination of chitosan and sodium carboxymethylcellulose (Na-CMC) that could control in vitro release of metronidazole. Methods: Prediction of the optimum formula was conducted using a factorial design with Design Expert 7.0.0 Trial software. Initial formula that was used to predict the optimum formula consisted of four formulas with the ratio of chitosan and sodium carboxymethylcellulose polymer is $0.5: 1.5 ; 1.0: 1.5 ; 0.5: 3.0$; and 1.0:3.0 respectively. Results: Variations in the concentration of $\mathrm{Na}-\mathrm{CMC}$ and chitosan could influence drug release, namely in formula I with drug release kinetics following higuchi kinetics and release mechanism following fickian diffusion mechanism. Whereas, in formula 4 the physical preparation was the highest mucoadhesive strength compared to the other formulas due to an increase in the concentration of chitosan and sodium carboxymethylcellulose. So that the combination between chitosan and Na-CMC can be a model of metronidazole release from the matrix hydrogel which ranges from $55.633 \%-68.319 \%$ in 240 minutes. The observation results showed the optimum formula with a ratio of chitosan and sodium carboxymethylcellulose polymers of $1.0 \%$ (chitosan) and 3.0\% (sodium carboxymethylcellulose), with a response to developing ability of 96.95\%; mucoadhesive strength of $0.1911 \mathrm{~N} / \mathrm{cm} 2$; drug release of $67.457 \%$. Based on the independent test sample t-test on the SPSS 22 trial program explained that the formula of the observation results were not significantly different from the predicted results (p-value > 0.05). Conclusion: The results showed that the factorial design method can be used to determine the optimum formula for metronidazole mucoadhesive hydrogels.
\end{abstract}

Keywords: metronidazole, chitosan, sodium carboxymethylcellulose, hydrogels, factorial designs

\begin{abstract}
Abstrak
Pendahuluan: Metronidazol merupakan suatu antibiotik yang biasa digunakan dalam mengobati infeksi Helicobacter pylori. Metronidazol mempunyai kelarutan yang tinggi dalam asam. Untuk mengoptimalkan kelarutan tersebut maka dibuatlah hidrogel mukoadhesif yang dapat mempertahankan waktu tinggal di lambung lebih lama sehingga terapi infeksi H.pylori lebih optimal. Tujuan: untuk mendapatkan formula optimum dari hidrogel dengan kombinasi polimer kitosan dan natrium karboksimetilselulosa yang dapat mengontrol pelepasan metronidazol secara in vitro. Metode: Metode yang digunakan untuk memprediksi formula optimum menggunakan desain faktorial. Rancangan formula awal untuk memprediksi formula optimum terdiri dari 4 formula dengan perbandingan polimer kitosan dan natrium karboksimetilselulosa berturut-turut $0,5: 1,5 ; 1,0: 1,5$; 0,5:3,0; dan 1,0:3,0. Hasil: Variasi konsentrasi dari Na-CMC dan kitosan dapat mempengaruhi pelepasan obat, yakni pada formula I dengan kinetika pelepsan obat mengikuti kinetika higuchi dan mekanisme pelepasan mengikuti mekanisme difusi fickian. Sedangkan, pada formula 4 memiliki sediaan fisik yaitu kekuatan mukoadhesif yang paling tinggi dibandingkan formula yang lain karena adanya peningkatan konsentrasi kitosan
\end{abstract}


dan natrium karboksimetilselulosa (Na-CMC). Sehingga kombinasi antara kitosan dan Na-CMC dapat menjadi model pelepasan metronidazol dari matriks hidrogel yakni pada rentang 55,633\% - 68,319\% dalam waktu 240 menit. Hasil observasi menunjukkan formula optimum dengan perbandingan polimer kitosan dan natrium karboksimetilselulosa sebesar 1,0\% (kitosan) dan 3,0\% (natrium karboksimetilselulosa), dengan respon untuk kemampuan mengembang sebesar 96,95\%; kekuatan mukoadhesif sebesar 0,1911 N/cm2; pelepasan obat sebesar $67,457 \%$. Berdasarkan uji independent sampel t-test pada program SPSS 22 trial menjelaskan bahwa formula hasil observasi tidak berbeda siginifikan dengan hasil prediksi ( $p$-value $>0,05)$. Kesimpulan: Hasil menunjukkan bahwa metode desain faktorial dapat digunakan untuk menentukan formula optimum dari hidrogel mukoadhesif metronidazol.

Kata kunci: metronidazol, kitosan, natrium karboksimetilselulosa, hidrogel, desain faktorial

\section{PENDAHULUAN}

Ulkus peptik merupakan suatu keadaan dimana terjadi kerusakan pada lapisan mukosa sampai dengan lapisan otot saluran cerna yang disebabkan oleh adanya peningkatan bakteri Helicobacter pylori (H. pylori) yang terdapat di dalam lambung (Aziz, 2002; Zhang dkk., 2005). Di negara berkembang $H$. pylori menginfeksi orang dewasa sebanyak $80-90 \%$ dari populasi dan sekitar 60 - 90\% pasien yang mengalami tukak lambung terinfeksi oleh $\mathrm{H}$. Pylori (Arora dkk., 2012; Farida dkk., 2009).

Pengobatan konvensional seperti sediaan tablet dan kapsul dalam mengatasi infeksi $H$. Pylori sering mengalami kegagalan yang disebabkan oleh permeabilitas obat yang kurang baik, kadar obat yang sedikit di dalam lambung dimana sediaan obat yang tepat untuk infeksi $H$. pylori sediaan yang dapat mempertahankan obatnya lebih lama di lambung karena H. pylori tinggal dalam sel epitel mukosa lambung (De la Torre dkk., 2003).

Metronidazol merupakan salah satu antibiotik yang digunakan untuk mengatasi infeksi $H$. Pylori (Lacy dkk., 2009; Rediguieri dkk., 2011). Metronidazol mempunyai kelarutan yang tinggi pada $\mathrm{pH}$ asam, yaitu $30,6 \mathrm{mg} / \mathrm{mL}$ pada $\mathrm{pH} 1$ dan kelarutan yang rendah pada pH basa yaitu $11,6 \mathrm{mg} / \mathrm{mL}$ pada $\mathrm{pH} 7$ (Rediguieri dkk., 2011). Untuk memaksimalkan kelarutan metronidazol yang tinggi di lambung dan waktu tinggal di lambung, maka dikembangkan sistem penghantaran obat gastroretentif dalam bentuk sediaan hidrogel. Hidrogel dapat meregulasi pelepasan obat melalui perubahan volume gel yang diinduksi oleh lingkungannya seperti kondisi $\mathrm{pH}$, sehingga dapat diterapkan pada penghantaran metronidazol agar terlepas di lambung.

Selain itu, kitosan dan natrium karboksimetilselulosa merupakan polimer yang memiliki sifat mukoadhesif (Tangri \& Madhav, 2011).
Penelitian sebelumnya membuat hidrogel dengan polimer kitosan, polivinil pirolidon, dan asam poliakrilat dengan bahan aktif klaritomisin ternyata dapat meningkatkan waktu tinggal obat tersebut di lambung sehingga untuk mengobati infeksi $H$. pylori pada ulkus peptik lebih optimal (Gupta dkk., 2010). Hidrogel yang disintesis dengan bahan dasar kitosan dengan penambahan polivinil alkohol sebagai agen penguat, diperoleh hidrogel yang dapat mengembang pada $\mathrm{pH}$ 1,2 dan menyusut pada pH 7 (Gupta dkk., 2010).

Penelitian menunjukan bahwa kitosan dan natrium karboksimetilselulosa (Na-CMC) mempunyai sifat mukoadhesif yang baik. Hidrogel yang dibuat dari kitosan yang dikombinasikan dengan polivinil pirolidon dan asam poliakrilat ternyata dapat memperpanjang waktu tinggal klaritomisin dan dapat mengontrol pelepasan klaritomisin sehingga terapi infeksi H. pylori lebih optimal (Tangri \& Madhav, 2011). Metronidazol yang didesain menjadi hidrogel mukoadhesif dapat meningkatkan waktu tinggalnya di lambung sehingga diharapkan terapi infeksi $H$. pylori dapat lebih optimal.

\section{BAHAN DAN METODE Bahan}

Metronidazol diperoleh dari Wuhan Wuyao Pharmaceutical dengan nomor batch: C04-W103023, kalsium klorida diperoleh dari Merck, kitosan dari Biotech Surindo ddengan nomor batch 10A0215.F.HM.CHC, natrium karboksilmetilselulosa (Na-CMC) dari Brataco, asam klorida dari Merck, serta natrium klorida diperoleh dari Merck.

Alat

Alat-alat yang digunakan dalam penelitian ini adalah timbangan analitik (BEL model M254Ai), lemari asam (ESCO model EBC-4A0), magnetic stirrer (Schott model D-55122 Mainz), pH meter (HANNA 
tipe HI98107), mikropipet (Socorex, Acura Manual Model 815.0010Y), spektrofotometer UV-Vis (Shimadzu 2450 \& Genesys 10s UV-Vis).

\section{Metodologi}

\section{Pembuatan sediaan hidrogel metronidazol}

Variasi konsentrasi dari natrium karboksimetilselulosa dan kitosan tertera pada Tabel 1. Larutan Na-CMC (Brataco) dipersiapkan dengan cara melarutkan Na-CMC dengan akuades dan dilanjutkan dengan melakukan pengadukan dengan magnetic stirrer (Schott model D-55122 Mainz) pada suhu ruang. Larutan kitosan dipersiapkan dengan cara melarutkan kitosan dalam asam asetat $1 \%$, setelah itu dilakukan pengadukan dengan magnetic stirrer hingga kitosan terlarut sepenuhnya (Abu-Jdayil \& Fara, 2013).
Sebanyak $250 \mathrm{mg}$ metronidazol dilarutkan dalam $10 \mathrm{~mL}$ dapar $\mathrm{pH} 1,2$ kemudian ditambahkan ke dalam larutan Na-CMC dan diaduk selama 45 menit untuk memfasilitasi penetrasi molekul metronidazol ke dalam larutan Na-CMC. Selanjutnya, larutan Na-CMCMetronidazol diteteskan ke dalam larutan kitosan yang telah mengandung kalsium klorida $\left(\mathrm{CaCl}_{2}\right) \quad 2 \%$ menggunakan hypodermic syringe $5 \mathrm{~mL}$ dan campuran diaduk secara konstan dengan kecepatan 100 rpm untuk membentuk kompleks kitosan-metronidazol-NaCMC (Santoso, 2013). Hidrogel yang terbentuk kemudian dikeringkan pada suhu kamar. Hidrogel yang telah kering selanjutnya dipersiapkan untuk analisis lebih lanjut.

Tabel 1. Hasil pengujian profil hidogel mukoadhesif metronidazol

\begin{tabular}{|c|c|c|c|c|c|}
\hline \multirow[b]{2}{*}{ Kode Formula } & \multicolumn{2}{|c|}{ Variabel } & \multirow{2}{*}{$\begin{array}{c}\text { Index } \\
\text { Pengembangan } \\
(\% / \text { jam })\end{array}$} & \multirow{2}{*}{$\begin{array}{c}\text { Kekuatan } \\
\text { Mukoadhesif } \\
\left(\mathrm{N} / \mathrm{cm}^{2}\right)\end{array}$} & \multirow{2}{*}{$\begin{array}{c}\text { Persentase kumulatif obat } \\
\left(\mathrm{t}_{240}\right) \\
(\%)\end{array}$} \\
\hline & $\mathrm{X}_{1}$ & $\mathrm{X}_{2}$ & & & \\
\hline F1 & -1 & -1 & $60,691 \pm 1,775$ & $0,141 \pm 0,007$ & $68,319 \pm 1,044$ \\
\hline $\mathrm{F} 2$ & 1 & -1 & $48,845 \pm 1,186$ & $0,164 \pm 0,011$ & $65,618 \pm 2,307$ \\
\hline F3 & -1 & 1 & $139,667 \pm 0,710$ & $0,183 \pm 0,005$ & $55,633 \pm 2,001$ \\
\hline $\mathrm{F} 4$ & 1 & 1 & $96,583 \pm 0,770$ & $0,192 \pm 0,006$ & $66,672 \pm 1,808$ \\
\hline \multicolumn{3}{|c|}{ Level variabel } & \multicolumn{2}{|c|}{ Konsentrasi rendah (-1) } & Konsentrasi tinggi (1) \\
\hline \multicolumn{3}{|c|}{ Kitosan $(\%)$} & \multicolumn{2}{|c|}{0,5} & 1 \\
\hline \multicolumn{3}{|c|}{ Na Karboksimetilselulosa (\%) } & \multicolumn{2}{|c|}{1,5} & 3 \\
\hline
\end{tabular}

Keterangan: kitosan dilarutkan dalam $10 \mathrm{~mL}$ larutan asam asetat 1\%; natrium karboksimetilselulosa dilarutkan dalam $10 \mathrm{~mL}$ Akuades. Metronidazol yang digunakan sebanyak $250 \mathrm{mg}$ : larutan $\mathrm{CaCl}_{2} 10 \mathrm{~mL}$

\section{Pembuatan larutan dapar pH 1,2}

Pembuatan larutan dapar pada $\mathrm{pH} 1,2$ merujuk pada ketentuan yang ditetapkan pada farmakope Indonesia edisi keempat dengan menggunakan $\mathrm{HCl}$ pekat sebanyak $7 \mathrm{~mL}$ dilarutkan dalam $500 \mathrm{~mL}$ akuades. $\mathrm{NaCl}$ sebanyak $2 \mathrm{~g}$ dilarutkan dalam $100 \mathrm{~mL}$ akuades. Larutan $\mathrm{NaCl}$ kemudian ditambahkan ke dalam larutan $\mathrm{HCl}$ dan ditepatkan dengan akuades hingga 1 L. Selanjutnya campuran tersebut diukur pHnya menggunakan pH meter (DepKes RI, 1995).

\section{Pengukuran kadar metronidazol}

Pengukuran kadar metronidazol dengan menggunakan spektrofotometer UV-Vis (Shimadzu 2450 \& Genesys 10s UV-Vis double beam). Metronidazol sebanyak $100 \mathrm{mg}$ yang ditimbang secara seksama terlebih dahulu dilarutkan kedalam larutan dapar asetat $\mathrm{pH} \quad 1,2$ dan diaduk selama 10 menit dengan kecepatan $500 \mathrm{rpm}$. Setelah terlarut seluruhnya larutan tersebut dibuat dalam berbagai seri konsentrasi yakni $6,9,12,15,18$ dan $21 \mathrm{ppm}$. Pengukuran metronidazol menggunakan spektrofotometer berada pada panjang gelombang maksimum $276,8 \mathrm{~nm}$. Proses pembuatan seri larutan dan pengukuran untuk kurva baku dilakukan repitisi 6x yang dilakukan dari larutan baku yang tersedia. Metode penetapan kadar ditetapkan dengan melakukan verifikasi metode yang meliputi linearitas, akurasi dan presisi. Hasil yang diperoleh pada pengukuran tersebut nilai liniaritas 0,9997 , nilai akurasi dan presisi berturut-turut adalah pada rentang 98,124 - 100,198 dan 0,915 - 1,963.

\section{Uji kemampuan mengembang}

Pengujian kemampuan mengembang hidrogel dilakukan dalam dapar $\mathrm{pH}$ 1,2 yang menggambarkan kondisi cairan lambung. Hidrogel yang telah dikeringkan ditimbang $\pm 5 \mathrm{mg}$ dan ditempatkan dalam larutan dapar pada suhu kamar. Sampel di keluarkan dari larutan dapar pada interval waktu 1 jam selama 8 jam perendaman. Kelebihan air hidrogel dibersihkan dari permukaan sampel dengan menggunakan kertas saring, kemudian ditimbang bobot hidrogel basah. Rasio pengembangan hidrogel ditentukan dengan persamaan 1 (He, 2007). 


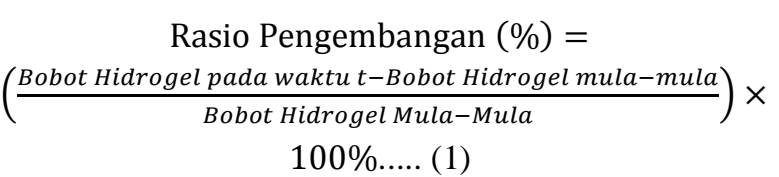

Uji kekuatan mukoadhesif

Kekuatan mukoadhesif diukur dengan menggunakan modifikasi keseimbangan timbangan. Hidrogel yang diuji ditempatkan pada mukosa usus sapi yang terdapat didalam dapar. Kemudian, pada sisi yang lain tambahkan air perlahan dengan kecepatan 100 tetes per menit. Penambahan air dihentikan saat hidrogel terlepas dari mukosa usus sapi. Berat air yang menyebabkan terlepasnya hidrogel dihitung sebagai berat air $(\mathrm{g})$ yang ditentukan berdasarkan persamaan 2 dan 3 (Rajput dkk., 2010).

$$
\begin{aligned}
& \text { Daya Adhesi }(\mathrm{N})=\frac{\text { Berat air }(\mathrm{g})}{1000} \times 9,81 \ldots \ldots \ldots \ldots \ldots \ldots \ldots \ldots \ldots \\
& \text { Kekuatan Mukoadhesif }\left(\mathrm{N} / \mathrm{cm}^{2}\right)=\frac{\text { Daya Adhesi }(\mathrm{N})}{\text { Luas Permukaan }\left(\mathrm{cm}^{2}\right)} .
\end{aligned}
$$

\section{Uji pelepasan obat secara in vitro}

Tiap formula hidrogel metronidazol dilakukan uji pelepasan metronidazol dari polimer hidrogel dengan metode uji disolusi. Digunakan $900 \mathrm{~mL}$ larutan dapar $\mathrm{pH} \quad 1,2$ dalam gelas beaker dan pengadukan menggunakan magnetic stirrer dengan kecepatan $100 \mathrm{rpm}$ pada suhu $37 \pm 0,5^{\circ} \mathrm{C}$. Pengujian dalam medium $\mathrm{pH}$ 1,2 dilakukan selama 4 jam. Sampel larutan diambil pada menit ke-5, 10, 15, 30, 45, 60, 90, $120,150,180,240$ dan dianalisis menggunakan spektrofotometer UV-Vis pada panjang gelombang maksimum metronidazol. Hasil uji disolusi dimasukkan ke dalam persamaan orde ke-nol, orde kesatu dan Higuchi untuk melihat kinetika reaksi obat serta persamaan Kosmeyer-Peppas untuk melihat mekanisme pelepasan obat (Déat-Lainé dkk., 2013; Lin dkk., 2005).

\section{HASIL DAN PEMBAHASAN}

Hasil penelitian menunjukan bahwa panjang gelombang maksimum metronidazol yaitu $277 \mathrm{~nm}$ pada pelarut larutan dapar $\mathrm{pH}$ 1,2. Data panjang gelombang maksimum tersebut digunakan untuk membuat kurva baku dalam berbagai konsentrasi sehingga diperoleh persamaan yang akan digunakan untuk menghitung jumlah obat yang dilepaskan setiap satuan waktu tertentu.

\section{Uji kemampuan mengembang}

Pengujian kemampuan mengembang hidrogel dilakukan dalam medium dapar $\mathrm{pH} \quad 1,2$ yang menggambarkan kondisi medium lambung tanpa enzim. Pengujian ini bertujuan untuk mengetahui waktu pengembangan yang berkaitan dengan kemampuan hidrogel dalam mengontrol pelepasan obat dari dalam matriks polimernya. Hasil pengujian (Gambar 1) menunjukan bahwa lama pengembangan hidrogel berbanding lurus dengan kemampuan pengembangan hidrogel, semakin lama waktu pengembangan akan meningkatkan persen pengembangan dari hidrogel. Adanya penetrasi air secara bebas ke dalam hidrogel mengakibatkan air memenuhi pori-pori yang terdapat pada hidrogel sehigga akan memperbesar derajat pengembangannya (Meng dkk., 2011). Formula 3 dan 4 menunjukan bahwa terjadi peningkatan yang signifikan pada 3 jam pertama yang selanjutnya diikuti dengan melambatnya pengembangan dan pengembangan stabil setelah pengujian memasuki jam ke-7. Peristiwa ini diawali dengan dengan terjadinya proses hidrasi ke dalam rantai polimer (Hoffman, 2012). Adanya penetrasi medium asam ke dalam rangka polimer pada waktu awal pengujian yang secara langsung akan mengakibatkan protoniasasi gugus amin primer $\left(-\mathrm{NH}_{3}{ }^{+}\right)$pada kitosan sehingga terjadinya gaya tolakmenolak didalam rangka kitosan, muatan positif dari kitosan yang terbentuk dapat menyebabkan melemahnya interaksi dengan gugus karboksil Na-CMC, hal inilah yang menyebabkan terjadinya pengembangan yang cukup signifikan pada jam ke-3. Persamaan faktorial untuk respon kemampuan mengembang dapat di lihat pada persamaan 4 . Berdasarkan persamaan 4 tersebut, Na-CMC mempunyai pengaruh yang lebih besar dalam menurunkan kemampuan mengembang dan interaksi antara kitosan dan Na-CMC dapat menurunkan kemampuan mengembang hidrogel.

$$
\begin{aligned}
& \text { Kemampuan mengembang }=-0,710+3,141 \mathrm{~A}+5,791 \mathrm{~B}-3,209 \mathrm{~A} \\
& \text { Ket: } \mathrm{A}=\text { Proporsi Kitosan } \\
& \mathrm{B}=\text { Proporsi } \mathrm{Na}-\mathrm{CMC}
\end{aligned}
$$




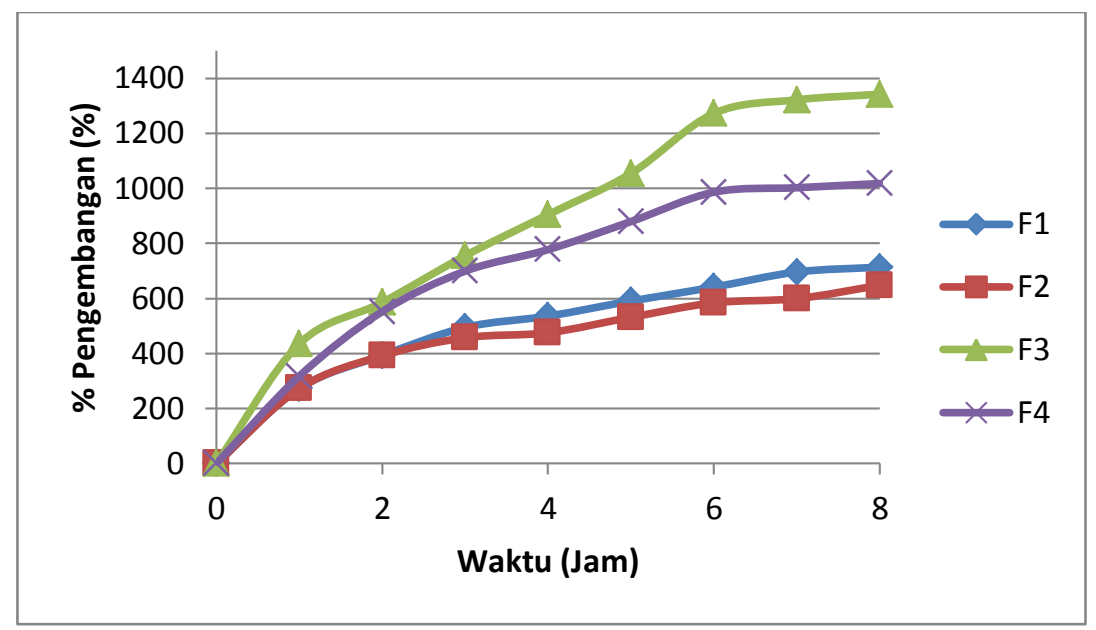

Gambar 1. Grafik hasil uji pengembangan hidrogel metronidazol dalam dapar asetat pH 1,2

\section{Uji kekuatan mukoadhesif}

Hasil pengujian memperlihatkan bahwa formula 4 mempunyai kekuatan mukoadhesif paling besar. Pada Gambar 2 memperlihatkan bahwa dengan adanya peningkatan konsentrasi kitosan dan $\mathrm{Na}-\mathrm{CMC}$ dapat meningkatkan kekuatan mukoadhesif. Persamaan faktorial respon kekuatan mukoadhesif dapat dilihat pada persamaan 5 .

$$
\begin{aligned}
& \text { Kekuatan Mukoadhesif }= \\
& \text { Ket: A }=\text { Proporsi Kitosan } \\
& \text { B }=\text { Proporsi Na-CMC }
\end{aligned}
$$

Berdasarkan persamaan 5 menunjukan bahwa dengan adanya peningkatan konsentrasi kitosan dan Na-CMC dapat meningkatkan kekuatan mukoadhesif secara signifkan ( $p$-value $<0,05)$. Hal ini sesuai dengan hasil penelitian menggambarkan formula 4 lebih besar kekuatan mukoadhesif daripada formula 1, 2 dan 3. Hal ini terjadi karena kitosan bersifat kationik dan memiliki gugus $-\mathrm{NH}_{2}$ yang mana pada kondisi asam akan terprotonasi membentuk $-\mathrm{NH}_{3}{ }^{+}$yang dapat berikatan dengan glikoprotein mukus yang bersifat anionik (asam sialat) serta permukaan sel mukosa yang bermuatan negatif sehingga membentuk ikatan ionik yang kuat. Kitosan juga berikatan hidrogen antara gugus hidrogel pada kitosan dengan senyawa penyusun mukosa lainnya (Deacon dkk., 2000). Na-CMC memiliki gugus - $\mathrm{COO}-$ yang pada suasana asam akan berada dalam bentuk molekul sehingga ikatan yang terjadi antara Na-CMC dengan komponen mukosa adalah ikatan hidrogen (El Kamel dkk., 2002). Namun dengan adanya interaksi antara kedua polimer dapat menurunkan kekuatan mukoadhesif. Hal ini disebabkan oleh terbentuknya ikatan gaya elektrostastik antara kitosan dan Na-CMC yang akan mengurangi ikatan polimer dengan mukosa lambung (El Kamel dkk., 2002).

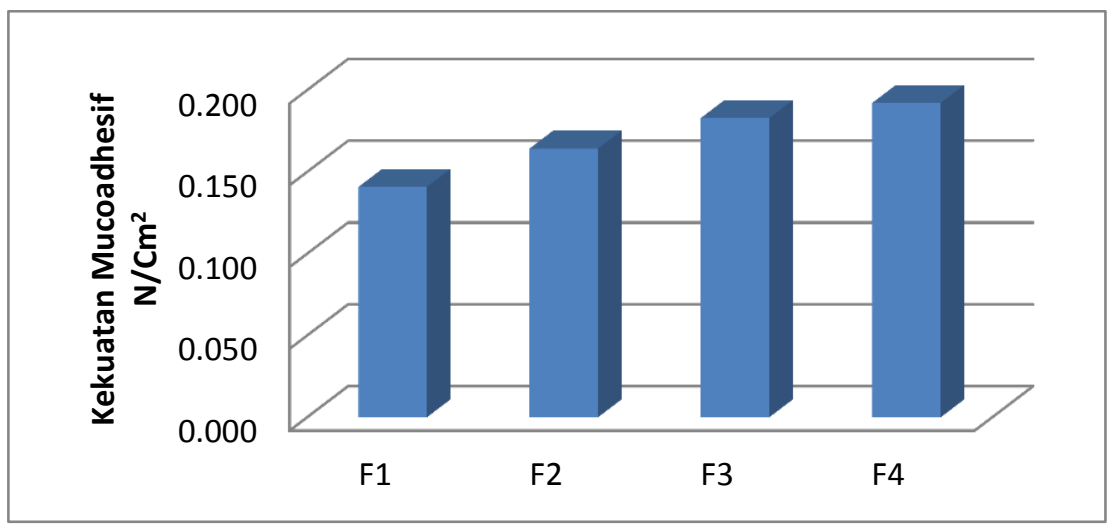

Gambar 2. Diagram hasil uji kekuatan mukoadhesif pada berbagai seri konsentrasi kitosan dan natrium karboksimetilselulosa pada berbagai formula 


\section{Uji Pelepasan Obat}

Uji pelepasan obat ini menggunakan alat disolusi yang dimodifikasi dan medium disolusi yang digunakan adalah dapar $\mathrm{pH}$ 1,2 yang menggambarkan kondisi cairan lambung. Data profil pelepasan metronidazol dari matriks hidrogel terhadap waktu ditunjukan pada Gambar 3.

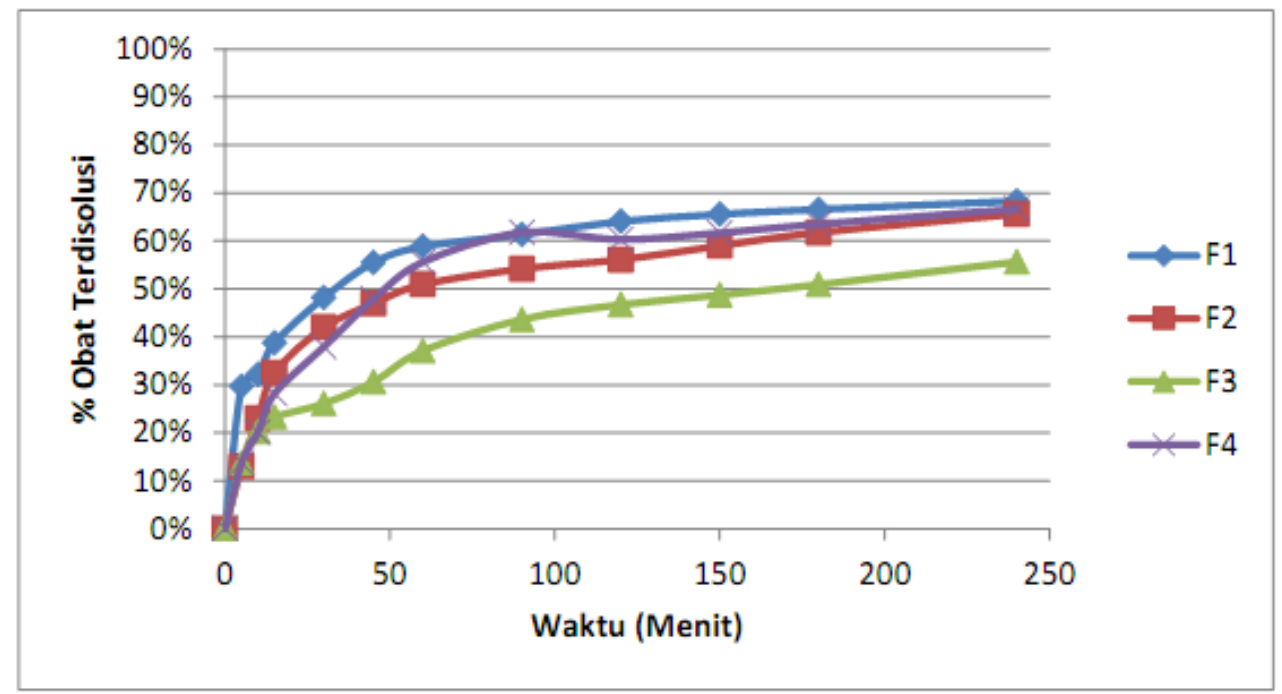

Gambar 3. Grafik hubungan antara profil obat terdisolusi dengan lama uji disolusi

Hasil penelitian (pada Tabel 1) menunjukan bahwa pelepasan obat paling tinggi yaitu pada formula 1 sebesar $68,31 \%$ dan paling rendah pada formula 3 sebesar 55,63\% selama 4 jam pengujian. Perbedaan yang terjadi antar formula dapat dikarenakan adanya variasi rasio konsentrasi polimer yang digunakan. Semakin kecil konsentrasi kitosan dan Na-CMC semakin besar obat yang akan terlepas dari matriks hidrogel. Pelepasan metronidazol dari matriks hidrogel dikendalikan oleh kinetika Higuchi. Hal ini dapat dilihat nilai $\mathrm{r}^{2}$ pada Tabel 2 yang mendekati 1 pada formula 1 sampai formula 4. Kinetika Higuchi mengambarkan bahwa jumlah obat yang terlepas sebanding dengan akar waktu dengan mekanisme pelepasan secara difusi Fickian (Komariah, 2012).
Matriks hidrogel yang digunakan juga termasuk matriks hidrofilik yang dapat mengembang pada medium asam, membentuk lapisan gel yang memungkinkan obat dapat berdifusi keluar melalui lapisan tersebut. Semakin lama kecepatan pelepasan obat semakin menurun, hal ini disebabkan karena jarak difusi obat dalam pori-pori sediaan semakin besar, sehingga membutuhkan waktu yang lebih lama untuk membawa obat keluar dari matriks (Banakar, 1992). Nilai eksponen pelepasan obat (n) pada persamaan Korsmeyer-Peppas menggambarkan mekanisme pelepasan obat yang dialami oleh sediaan tersebut. Tabel 3 memperlihatkan bahwa mekanisme pelepasan obat pada sediaan dikendalikan oleh difusi Fick karena nilai $\mathrm{n}<0,5$.

Tabel 2. Parameter pelepasan obat dari hidrogel $n=3$

\begin{tabular}{ccccccc}
\hline \multirow{2}{*}{ Formula } & \multicolumn{2}{c}{ Orde Nol } & \multicolumn{2}{c}{ Orde Satu } & \multicolumn{2}{c}{ Higuchi } \\
\cline { 2 - 7 } & $\mathrm{k}\left(\right.$ menit $\left.^{-1}\right)$ & $\mathrm{r}^{2}$ & $\mathrm{k}\left(\right.$ menit $\left.^{-1}\right)$ & $\mathrm{r}^{2}$ & $\mathrm{k}\left(\mathrm{menit}^{-1}\right)$ & $\mathrm{r}^{2}$ \\
\hline 1 & $0,154 \pm 0,001$ & $0,715 \pm 0,034$ & $0,003 \pm 0,000$ & $0,641 \pm 0,031$ & $3,0050 \pm 0,0185$ & $0,8741 \pm 0,0257$ \\
2 & $0,864 \pm 0,612$ & $0,717 \pm 0,093$ & $0,004 \pm 0,001$ & $0,545 \pm 0,081$ & $3,5562 \pm 0,3636$ & $0,8651 \pm 0,0766$ \\
3 & $0,169 \pm 0,007$ & $0,876 \pm 0,035$ & $0,005 \pm 0,000$ & $0,753 \pm 0,068$ & $3,1390 \pm 0,1242$ & $0,9684 \pm 0,0199$ \\
4 & $0,203 \pm 0,008$ & $0,692 \pm 0,031$ & $0,005 \pm 0,000$ & $0,756 \pm 0,020$ & $3,9887 \pm 0,1610$ & $0,8549 \pm 0,0278$
\end{tabular}

Keterangan: $\mathrm{n}$ : jumlah data; $\mathrm{r}^{2}$ : koefisien determinasi; $\mathrm{k}$ : konstanta pelepasan obat 
Tabel 3. Hasil perhitungan model pelepasan berdasarkan persamaan kosmeyer peppas; n=3

\begin{tabular}{cccc}
\hline \multirow{2}{*}{ Formula } & \multicolumn{3}{c}{ Kosmeyer Peppas } \\
\cline { 2 - 4 } & $\mathrm{k}\left(\right.$ menit $\left.^{-1}\right)$ & $\mathrm{r}^{2}$ & $\mathrm{n}^{\mathrm{b}}$ \\
\hline 1 & $0,0014 \pm 0,0000$ & $0,9538 \pm 0,0106$ & $0,2226 \pm 0,0007$ \\
2 & $0,0021 \pm 0,0004$ & $0,8916 \pm 0,0619$ & $0,3653 \pm 0,0515$ \\
3 & $0,0022 \pm 0,0001$ & $0,9736 \pm 0,0259$ & $0,3437 \pm 0,0072$ \\
4 & $0,0023 \pm 0,0001$ & $0,927 \pm 0,014$ & $0,4023 \pm 0,0000$ \\
\hline
\end{tabular}

Keterangan: n: jumlah data; nb: koefisien difusi; $\mathrm{r}^{2}$ : koefisien determinasi; k: konstanta pelepasan

Dengan demikian, pelepasan obat terjadi melalui difusi medium disolusi ke dalam matriks hidrogel (Setiastuti, 2011). Ketika medium disolusi berpenetrasi ke dalam matriks hidrogel, jaringan tiga dimensi hidrogel mengalami relaksasi, selanjutnya hidrogel akan mengembang sehingga medium yang masuk ke dalam matriks dapat membawa obat keluar melalui pori-pori matriks hidrogel secara difusi.
Persamaan faktorial untuk respon \% pelepasan obat ditunjukan pada persamaan 6. Berdasarkan persamaan 6 tersebut, adanya penurunan konsentrasi kitosan dan Na-CMC dapat meningkatkan $\%$ pelepasan obat, akan tetapi adanya interaksi kedua polimer tersebut dapat menurunkan \% pelepasan obat secara signifikan $(p$-value $<0,05)$.

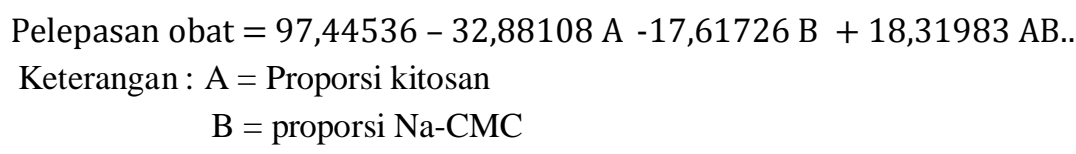

\section{Penentuan dan pengujian formula optimum}

Hasil analisis regresi desain faktorial (Tabel 4) pada parameter uji indeks pengembangan, kekuatan mukoadhesif, dan persentase pengambangan $\left(t_{240}\right)$ menunjukkan bahwa persamaan memiliki hubungan yang linear dengan perubahan konsentrasi dari polimer yang digunakan ditunjukkan dengan nilai $r^{2} \leq 0,9$.

Tabel 4. Hasil analisis regresi desain faktorial

\begin{tabular}{lccccc}
\hline Koefisien & B0 & b1 & b2 & b12 & R2 \\
\hline Indeks Pengembangan $(\% / J a m)$ & $-0,710$ & 3,141 & 5,791 & $-3,209$ & 0,999 \\
Kekuatan Mukoadhesif $\left(\mathrm{N} / \mathrm{Cm}^{2}\right)$ & 0,061 & 0,075 & 0,037 & $-0,018$ & 0,912 \\
pelepasan Obat $\mathrm{t}_{240}(\%)$ & 97,44536 & 32,88108 & $-17,61726$ & 18,31983 & 0,915 \\
\hline
\end{tabular}

Data-data hasil pengujian respon kemudian diolah dengan menggunakan program Desain Expert 7.0.0. Program ini akan memprediksikan kombinasi terbaik dari komponen-komponen yang dioptimasi yaitu kitosan dan Na-CMC. Formula optimum yang disarankan oleh desain adalah kitosan 1\%: Na-CMC $3 \%$. Pengujian parameter formula hidrogel optimum bertujuan untuk mengetahui apakah hasil parameter uji meliputi kemampuan mengembang, kekuatan mukoadhesif, dan pelepasan obat yang diperoleh sesuai dengan hasil prediksi dari program. Hasil pengujian dan analisis parameter hidrogel optimum dengan perbandingan polimer kitosan $-\mathrm{Na}-\mathrm{CMC}=1 \%: 3 \%$ dapat dilihat pada Tabel 5.

Tabel 5. Hasil pengujian dan analisis parameter formula optimum; $n=3 \pm S D$

\begin{tabular}{lccccc}
\hline \multicolumn{1}{c}{ Parameter } & Hasil Prediksi & 95\% PI low & 95\% PI high & Hasil Uji & Signifikansi \\
\hline Kemampuan Mengembang (\%) & 96,582 & 95,42 & 97,74 & $96,562 \pm 0,047$ & $\mathrm{p}>0,05$ \\
Kekuatan mukoadhesif $\left(\mathrm{N} / \mathrm{cm}^{2}\right)$ & 0,192 & 0,18 & 0,20 & $0,190 \pm 0,004$ & $\mathrm{p}>0,05$ \\
Pelepasan obat $(\%)$ & 66,672 & 3,71 & 4,27 & $67,457 \pm 2,427$ & $\mathrm{p}>0,05$ \\
\hline
\end{tabular}

Keterangan: n: jumlah data; PI: prediction interval

Berdasarkan hasil uji beda menggunakan independent sample t-test pada Tabel 4. menunjukkan bahwa nilai aktual dan nilai prediksi dari setiap parameter uji yang dihasilkan oleh formula optimum tidak berbeda signifikan dikarenakan nilai $p$-value > 0,05 . Hal ini mengindikasikan bahwa persamaan yang disarankan oleh program dengan metode desain faktorial dapat memprediksi nilai-nilai yang akan 
dihasilkan oleh setiap respon pada formula optimum hidrogel.

\section{KESIMPULAN}

Variasi konsentrasi dari natrium karboksimetilselulosa dan kitosan dapat mempengaruhi profil fisikokimia dari sediaan hidrogel mukoadhesif metronidazol. Variasi tersebut dapat mempengaruhi pelepasan obat yakni pada formula I dengan kinetika pelepasan obat mengikuti kinetika Higuchi dan mekanisme pelepasan mengikuti mekanisme difusi fickian. Sedangkan, pada formula 4 memiliki sifat fisik yaitu kekuatan mukoadhesif yang paling tinggi dibandingkan formula yang lain karena adanya peningkatan konsentrasi kitosan dan natrium karboksimetilselulosa. Kombinasi antara kitosan dan $\mathrm{Na}-\mathrm{CMC}$ dapat mengontrol pelepasaan metronidazol dari matriks hidrogel yakni pada rentang 55,633\% 68,319\% dalam waktu 240 menit. Formula optimum hidrogel memiliki nilai respon yang tidak berbeda signifikan dengan nilai observasi $(\mathrm{p} \geq 0,05)$ dengan komposisi optimum kombinasi formula berturut-turut kitosan dan $\mathrm{Na}$ karboksimetilselulosa adalah $1 \%$ serta $3 \%$. Hasil tersebut menunjukkan bahwa metode desain faktorial dapat digunakan untuk menentukan formula optimum dari hidrogel mukoadhesif metronidazol.

\section{DAFTAR PUSTAKA}

Abu-Jdayil, B. \& Fara, D. A. (2013). Modification of the Rheological Behaviour of Sodium Alginate by Chitosan and Multivalent Electrolytes. Italian Journal of Food Science; 25; 196-201.

Arora, S., Bisen, G. \& Budhiraja, R. (2012). Mucoadhesive and Muco-penetrating Delivery Systems for Eradication of Helicobacter Pylori. Asian Journal of Pharmaceutical Sciences; 6; 18-30.

Aziz, N. (2002). Peran Antagonis Reseptor H-2 Dalam Pengobatan Ulkus Peptikum. Sari Pediatri; 3, 222-226.

Banakar, U. V. (1992). Pharmaceutical Dissolution Testing. New York: Marcel Decker Inc.

De La Torre, P. M., Enobakhare, Y., Torrado, G. \& Torrado, S. (2003). Release of Amoxicillin from Polyionic Complexes of Chitosan and Poly(Acrylic Acid). Study of Polymer/Polymer and Polymer/Drug Interactions within the Network Structure. Biomaterials; 24; 14991506.
Deacon, M. P., McGurk, S., Roberts, C. J., Williams, P. M., Tendler, S. J., Davies, M. C., Davis, S. S. \& Harding, S. E. (2000). Atomic Force Microscopy of Gastric Mucin and Chitosan Mucoadhesive Systems. Biochemical Journal; 348; 557-563.

Déat-Lainé, E., Hoffart, V., Garrait, G., Jarrige, J. F., Cardot, J. M., Subirade, M., \& Beyssac, E. (2013). Efficacy of Mucoadhesive Hydrogel Microparticles of Whey Protein and Alginate for Oral Insulin Delivery. Pharmaceutical Research; 30; 721-734.

El Kamel, A. H., Sokar, M. S., Naggar, V. F. \& Gamal, S.A. (2002). Bioadhesive Controlled Release Metronidazol Vaginal Tablets. Acta Pharmaceutica; 52; 171-179.

Farida, A., Unita, M., Yulianita, F., Azhar, M. B. \& Yuwono. (2009). Sensitifitas dan Spesifisitas Pemeriksaan Helicobacter Pylori pada Saliva Penderita Gastritis Kronik dengan PCR. Majalah Patologi Indonesia; 17; 17-20.

Gupta, A. K., Maurya, S. D., Dhakar \& Singh, R. D., (2010). pH-Sensitive Interpenetrating Hydrogel for Eradication of Helicobacter Pylori. International Journal of Pharmaceutical Sciences and Nanotechnology; 3; 924-932.

He, X. S., Liao, Z. W., Huang, P. Z., Duan, J. X., Ge, R. S., Li, H. B. \& Geng, Z. C. (2007). Characteristics and Performance of Novel Water-Absorbent Slow Release Nitrogen Fertilizers. Agricultural Sciences in China; 6; 338-346.

Hoffman, A. S. (2012). Hydrogels for Biomedical Applications. Advanced Drug Delivery Reviews; 64; $18-23$

Komariah, E. (2012). Pengembangan Granul Mukoadhesif Diltiazem Tertahan Di Lambung Menggunakan Eksipien Koproses Karagenan dan Pragelatinasi Pati Singkong Propionat. Tesis; Fakultas Matematika dan Ilmu Pengetahuan Alam Universitas Indonesia, Jakarta.

Lacy, C. F., Amstrong, L. L., Goldman, M. P. \& Lance, L. L. (2009). Drug Information Handbook, 1st ed, Lexi Comp's Drug Information Handbooks. USA: Lexi-Comp Inc.

Lin, Y. H., Liang, H. F., Chung, C. K., Chen, M. C. \& Sung, H. W. (2005). Physically Crosslinked Alginate/N,O-carboxymethyl Chitosan Hydrogels with Calcium for Oral Delivery of Protein Drugs. Biomaterials; 26; 2105-2113. 
Meng, X., Li, P., Wei, Q., Zhang, H.-X. (2011). pH Sensitive Alginate-chitosan Hydrogel Beads for Carvedilol Delivery. Pharmaceutical Development and Technology; 16; 22-28.

Rajput, G. C., Dr. Majmudar, F. D., Dr. Patel, J. K., Patel, K. N., Thakor, R. S., Patel, B. P. \& Rajgor, N. B. (2010). Stomach Specific Mucoadhesive Tablets as Controlled Drug Delivery System - A Review Work. International Journal on Pharmaceutical and Biological Research; 1; 30-41.

Rediguieri, C. F., Porta, V. G., Nunes, D. S., Nunes, T. M., Junginger, H. E., Kopp, S., Midha, K. K., Shah, V. P., Stavchansky, S., Dressman, J. B. \& Barends, D. M. (2011). Biowaiver Monographs for Immediate Release Solid Oral Dosage Forms: Metronidazole. Journal of Pharmaceutical Sciences; 100; 1618-1627.

Depkes RI. (1995). Farmakope Indonesia, 4th ed. Jakarta: Depkes RI.
Santoso, I. L. (2013). Preparasi dan Evaluasi Hidrogel Natrium Diklofenak dengan Kitosan dan Natrium Alginat. Skripsi; Fakultas Farmasi Universitas Widya Mandala, Surabaya.

Setiastuti, A. D. (2011). Preparasi dan Karakterisasi Kitosan Suksinat sebagai Matriks pada Granul Lepas Lambat Mukoadhesif. Skripsi; Fakultas Matematika dan Ilmu Pengetahuan Alam Universitas Indonesia, Jakarta.

Tangri, P. \& Madhav, N. V. S. (2011). Oral Mucoadhesive Drug Delivery Systems. International Journal of Biopharmaceutics; 2; 36-46.

Zhang, Y., Argent, R. H., Letley, D. P., Thomas, R. J. \& Atherton, J. C. (2005). Tyrosine Phosphorylation of CagA from Chinese Helicobacter Pylori Isolates in AGS Gastric Epithelial Cells. Journal of Clinical Microbiology; 43, 786-790. 